\title{
Effects of intervention measures on irrational antibiotics/antibacterial drug use in developing countries: A systematic review
}

\author{
Godfrey S. Bbosa ${ }^{1,2^{*}}$, Geoff Wong ${ }^{2}$, David B. Kyegombe ${ }^{3}$, Jasper Ogwal-Okeng ${ }^{1}$ \\ ${ }^{1}$ Department of Pharmacology and Therapeutics, Makerere University College of Health Sciences, Kampala, Uganda; \\ *Corresponding Author: godfossa@yahoo.com \\ ${ }^{2}$ Department of Primary Care and Population Sciences, University of London, London, UK \\ ${ }^{3}$ Kampala International University Medical School, Ishaka Campus, Ishaka, Uganda
}

Received 15 November 2013; revised 19 December 2013; accepted 9 January 2014

Copyright (C) 2014 Godfrey S. Bbosa et al. This is an open access article distributed under the Creative Commons Attribution License, which permits unrestricted use, distribution, and reproduction in any medium, provided the original work is properly cited. In accordance of the Creative Commons Attribution License all Copyrights (C) 2014 are reserved for SCIRP and the owner of the intellectual property Godfrey S. Bbosa et al. All Copyright (C 2014 are guarded by law and by SCIRP as a guardian.

\section{ABSTRACT}

Irrational antibiotics/antibacterial (AB) drug use is a global problem, especially in developing countries. This results in an increased emergence of resistance to most common bacteria, higher cost of treatment, prolonged hospitalization and adverse drug reactions. Interventions measures have been instituted to avert the problem but it still persists. A systematic review was conducted to determine the effect of different interventions (education, managerial, diagnostic tests, regulatory, economic and multifaceted) on misuse of $A B$ drugs in developing countries. A total of 722 articles were retrieved and 55 were reviewed. About $10.9 \%$ of the studies were from Africa, $63.6 \%$ from Asia, 9.1\% from Latin America, and $16.4 \%$ from Southeastern Europe. A total of $52.7 \%$ of the studies were from hospital settings, $5.5 \%$ from outpatient departments, $\mathbf{2 1 . 8 \%}$ were from public health care facilities, $12.7 \%$ from private pharmacies/drug stores, and $7.3 \%$ from the communities. Education intervention had $27.3 \%$ studies, managerial had $20 \%$, managerial/education had $3.6 \%$, regulatory had $9.1 \%$, education/regulation had $9.1 \%$ and diagnostic had $3.6 \%$ studies. Multifaceted intervention had $27.3 \%$ studies, with $63 \%$ improvement in appropriate $A B$ doses prescribed, $2.6 \%$ mean number of $A B$ encounter reduction, $23 \% A B$ prescription reduction, $18.3 \%$ generic $A B$ prescription improvement, $32.1 \%$ reduction in $A B$ use, $89 \%$ reduction in $A B$ use in acute respiratory infection, $82 \%$ in surgery, $62.7 \%$ mean reduction in deliveries, $39 \%$ in STDs, $36.3 \%$ mean reduction in diarrhea, $14.6 \%$ mean reduction $A B$ use in malaria, and $6 \%-11 \%$ in the cost of treating bacteria-resistant organisms. Also noted was $6.3 \%$ reductions in mean $A B$ encounters after 1 month of intervention, and then increased to $7.7 \%$ after 3 months thus lacking sustainability. Multifaceted interventions were effective in reducing irrational $A B$ drug use in the various health facilities and communities as well as reduction in the emergence of resistance to the commonest bacteria in the developing countries though there was lack of sustainability or continuity of rational drug use over the time.

\section{KEYWORDS}

Antibiotic/Antibacterial Drugs; Interventions; Misuse; Systematic Review; Developing Countries

\section{INTRODUCTION}

Irrational antibiotics/antibacterial drug use is a global problem especially in the developing countries with poor healthcare systems. It refers to the failure to complete treatment, skipping of doses, reuse of leftovers and this leads to sub-therapeutic doses or toxicity of the drugs as well as failure of eradicating infectious bacteria and potentially promoting the emergence of resistance [1]. Irrational drug use may involve drug misuse and/or inappropriate drug use and many other issues (Box 1).

Misuse of $\mathrm{AB}$ drugs involves many key players including various cadres of healthcare workers such as 
Box 1. Definition of the terms as used in the review.

\section{Definitions:}

Rational use of drugs: is where patients receive medications appropriate to their clinical needs, in doses that meet their own individual requirements for an adequate period of time and at the lowest cost to them and their community [2-4].

Irrational drug use: is where there is over-prescribing, extravagant prescribing, incorrect prescribing, under-prescribing, and multiple prescribing as well as indiscriminate drug use [2-4].

Drug misuse: Is the improper, unlawful or incorrect use and misapplication of drugs (refers to both irrational and inappropriate drug use) [5-9]

Inappropriate use: Refers to use of wrong drug, indication, wrong patient and with wrong patient information as well as in inadequate doses, wrong duration and indiscriminate drug use [1,5-8,9].

Self-medication: is the "use of drugs or pharmaceutical products by the consumer to treat self recognized disorders or symptoms or the intermittent or continued use of the medication prescribed by the physicians for a chronic or recurring diseases or symptoms" [10].

Antibiotics: Are chemical substances or compounds produced by microorganisms such as bacteria, yeasts and molds and they inhibit growth or kill other micro-organisms [11-13].

Antibacterial: Are agents/drugs that inhibit growth or kill bacteria. Antibiotics are a subset of antibacterial agents [11-13].

Intervention measures: Refers to the various measures that can be used to prevent, reduce or avert the misuse of the medicines such as antibiotics/antibacterial agents or drugs [1,14-20].

Antimicrobial resistance (AMR): Is resistance of microorganisms like bacteria, fungi, viruses and some parasites to antimicrobial agents/drugs (antibiotics and antibacterial, antifungals, antivirals, and antimalarials) to which they were originally sensitive (failure to stop their multiplication or killing them) [5,6,12,21].

prescribers and dispensers; patients or consumers and the communities [5-9,22-24]. Inappropriate and overuse of antibiotics have been a contributing factor to the emergence of bacterial resistance globally. The problem is further exacerbated by self-medication of these drugs by individuals without the guidance of a qualified health workers and also the non-therapeutic use of antibiotics as growth promoters in agriculture [5-9,22-24]. The inappropriate prescriptions of these drugs by both the trained and untrained health care workers for conditions where there is no proven benefit of such therapy like in the viral infections has lead to the development of antimicrobial resistance and unnecessary expense to patients and to the healthcare system as a whole [9,22-25].

Globally, more than $50 \%$ of all medicines are prescribed, dispensed, or sold inappropriately, while $50 \%$ of patients fail to take them correctly [17,26,27]. A survey done in the United States reported that antibiotics/antibacterial agents or drugs were prescribed to $44 \%$ of patients with common cold, $46 \%$ with upper respiratory tract infections and $75 \%$ with bronchitis and that children aged 0 - 4 years received $53 \%$ antibiotics in their prescriptions [28]. It is reported that up to $75 \%$ of antibiotics/antibacterial drugs are prescribed inappropriately in teaching hospitals in developing countries [26]. Large community surveys in 9 countries on the antibiotics/antibacterial drug compliance, reported that $10 \%-47 \%$ of patients did not complete the course of antibiotic therapy and $4 \%-41 \%$ reported saving leftover antibiotics for future use [1]. A similar study in Turkey also reported that $53.7 \%$ patients had leftover antibiotics of which $77.0 \%$ saved them for future use, $4.6 \%$ gave them away and $18.4 \%$ threw them away [1]. All these problems of antibiotic misuse are due to the fact that only $30 \%$ of the developing countries have fully functional drug regulatory authorities and that many drugs or medicines invented are never tested for potency or efficacy [26]. Also there is a common cultural belief among the communities about antibiotics, that there is a pill for every symptom and that antibiotics can heal many illnesses and believe that injections are more powerful than pills. Also the patients demands and the satisfaction of their expectations and demands of quick relief, clinician prescribe drug for every single complaint leading to a belief that "every ill has a pill” thus contributing to the polypharmacy $[17,26,27]$.

The misuse of antibiotics has become integrated into the local culture of the various communities of the different countries and this attitude has greatly favored the emergence of resistance to most of the common antibiotics used globally [17,29-34]. The $A B$ resistance is 
currently a serious global concern since a few available drugs are no longer effective to the commonest bacterial infections in both humans and animals. However, many various types of intervention measures have been put in place at various levels of healthcare facilities and in the communities to address the problem of irrational antibiotic/antibacterial drug use, but the problem has still persisted and it is worse in some countries especially in developing nations [35-38]. Also a number of intervention research studies have been conducted at various health care facilities and in the communities of developing countries to address the problem of irrational $A B$ use. However, whereas intervention studies have been done in medical practice and healthcare facilities worldwide, no such a similar ones have been done in veterinary practice and agriculture and yet same drugs are used in controlling of bacterial infections and contaminants. This therefore worsens the emergence of antibacterial resistance in various healthcare facilities and the general public.

However, even though various types of intervention measures including educational, managerial, regulatory and economic/financial and multifaceted interventions (Box 2) [3,4,39-41], have been put in place at various levels of healthcare facilities such as hospitals, private and public pharmacies, drug stores, outpatient departments and the communities to address the problem of irrational $\mathrm{AB}$ drug use, the problem seem to be on in- crease especially in developing countries. The misuse of these drugs has been reported to occur at three levels: community, healthcare facilities and national level in both the public and private healthcare providers. The problem has resulted in increased healthcare cost of treatment, emergence of antibiotic/antibacterial drug resistance, treatment failures, polypharmacy, adverse drug reactions, prolonged hospitalization, wasted medication and increased return visits to the healthcare facilities as well as psychosocial problems experienced by the patients and their families [4,14,27]. This therefore calls for the review of the published primary intervention studies on irrational antibiotics/antibacterial drug use and assess their impact in the various healthcare facilities and communities. The aim of the review was to establish the effects of various primary intervention measure studies on the irrational use of antibiotics/antibacterial drugs in developing/poor nations [3,4].

\section{METHODS}

\subsection{Study Design}

It was a systematic review study that evaluated the effects of various primary intervention measure studies on the irrational use of antibiotics/antibacterial drugs in developing/poor nations.

Box 2. Standard categories of intervention measures used in the study [3,4,39-41].

\begin{tabular}{|c|c|}
\hline \multicolumn{2}{|c|}{ Various intervention measure issues for consideration } \\
\hline $\begin{array}{l}\text { 1. Educational intervention measures } \\
\text { 1) Goal: to inform or persuade } \\
\text { 1) Training } \\
\text { - Changes in formal education } \\
\text { - In-service training-seminars } \\
\text { - Face-to-face outreach (discussions) } \\
\text { - Clinical supervision and consultation } \\
\text { 2) Printed materials } \\
\text { - Clinical literature and newsletter } \\
\text { - Formularies or therapeutic manuals } \\
\text { - Persuasive print materials } \\
\text { 3) Media-based approaches } \\
\text { - Posters } \\
\text { - } \quad \text { Radio tapes and plays } \\
\end{array}$ & $\begin{array}{l}\text { 2. Managerial intervention measures } \\
\text { - Goal: Structure decisions } \\
\text { 1) Prescribing and dispensing } \\
\text { - Treatment guidelines } \\
\text { - Structured drug order forms } \\
\text { - Automatic stop orders } \\
\text { - Course-of-therapy packaging } \\
\text { - } \text { Audective labeling } \\
\text { - Required consultations or justifications } \\
\text { 2) Standard diagnostic tools and laboratories }\end{array}$ \\
\hline $\begin{array}{l}\text { 3. Regulatory intervention measures } \\
\text { - Goal: To restrict decisions } \\
\text { - } \text { Market controls } \\
\text { - } \text { Conning previously registered drugs } \\
\text { - } \text { Prescribing contents in drug advertisement } \\
\text { - } \text { Limitation of drug supply in public sector } \\
\text { - } \text { Required generic prescribing } \\
\text { - } \text { Restricting on number or quantity of drugs per patient } \\
\text { - }\end{array}$ & $\begin{array}{l}\text { 4. Economic /financing intervention measures } \\
\text { - Pricing of drugs according to health impact } \\
\text { - Patient cost-sharing } \\
\text { - Economic incentives }\end{array}$ \\
\hline 5. Education/managerial interventions & 6. Education/regulation \\
\hline 7. Multifaceted interventions & \\
\hline
\end{tabular}




\subsection{Search Strategy}

\subsubsection{Databases}

The search strategy plan was used to retrieve articles and abstracts from various databases with modifications and these have been used by other researchers in identifying useful articles [1,29,42-45]. These databases that were searched for intervention measure studies on the irrational use of antibiotics/antibacterial drugs in developing/poor nations included PubMed (1985-2010), MEDLINE (1985-2010), CINAHL (1985-2010), EmBASE, Web of Science, International Pharmaceutical Abstracts (IPA), Cochrane Library (1985-2010), Cochrane Database of Systematic Reviews (CDSR), Database of Abstracts of Reviews of effectiveness (DARE), HINARI, WHO website, INRUD database and UCL library.

\subsubsection{Internet}

The search engines using the search terms in Table 1 were used to identify more other articles using the following search engines:

- www.yahoo.com

- Google scholar

- Google search

\subsubsection{Pearling}

This method was used to identify and then retrieve useful articles and it involved looking at the reference section of the already retrieved articles and useful references were indentified and finally traced the articles that were missed in the search.

\subsubsection{Hand Searching}

Hand-searching using manual method of searching in the print and electronic journals for citations and references (snowballing) was also used. It involved manually screening the peer-reviewed biomedical journals, conference proceedings and other publications on the web for the best-available evidence [46-48].

\subsubsection{Gray Literature (Unpublished Literature)}

Many gray literature materials were found via an emerging form of scholarly communication known as institutional repositories such as the UCL library repositories and it also had links to other institutions where useful information were obtained. The electronic databases are maintained by universities in order to make their scholarly output available online. Conference papers and dissertations by faculty and technical reports by research organizations were among the types of documents found in these repositories. The following resources were reported to deposit gray literature especially the Health Sciences Gray Literature Resources and they were used to retrieve useful information [49]. They were used to avoid publication bias [50-55]. The search-
Table 1. Search terminology to be used in literature review.

\begin{tabular}{cc}
\hline Connector & Search term \\
\hline OR & Antibacterial agents (MeSH term) \\
OR & Antibacterial agent (Free text) \\
OR & Antibacterial agent (Pharmacological action) \\
OR & Antibiotic (MeSH term) \\
AND & Antibiotic (All field) \\
OR & Misuse (All fields and Free text) \\
OR & Irrational (All fields) \\
AND & Inappropriate (All fields and Free text) \\
OR & Intervention* (MeSH term) \\
OR & Intervention (Free text) \\
AND & Trial (All fields) \\
OR & Impact (All fields) \\
OR & Effect (Free text) \\
OR & Regulatory (Text word) \\
OR & Managerial (Text word) \\
OR & Financial (Text word) \\
AND & Educational (Text word) \\
OR & Developing countr (All field) \\
OR & Poor ${ }^{*}$ near nation* (All field) \\
OR & Poor ${ }^{*}$ near countr* (All field) \\
AND & Low-income near countr* (All field) \\
\hline
\end{tabular}

"means truncation.

ing for unpublished studies (Gray-literature) was done through a manual search of conference proceedings, correspondence with experts, and a search of clinical trial registries for relevant documents on irrational $A B$ use $[56,57]$. Grey literature was identified by searching the Cochrane intervention database, INRUD/MSH database; WHO Medicines use database as well as the International Pharmaceutical abstracts (IPA). These databases contain unpublished material like presentations, dissertations, conference abstracts and pre-publication manuscripts. Some gray literature was also obtained from various institutional repositories. The gray literature about the effects of interventions measures on misuse of antibiotics/antibacterial medications in developing countries was got by conducting a thorough search through institutional and discipline-based online repositories [49] and as well as using the Google scholar search engine.

\subsection{Search for Articles on Intervention on Antibiotic/Antibacterial Misuse in Developing Countries}

The following search terms were used to identify articles through a systematic standardized process. Medical Subject Headings (MeSH) terminologies were used to 
maintain common terms across the search databases [58]. These search terms were piloted first and yielded some useful articles. The search strategy plan is shown in Table 1.

\subsection{Identification of Intervention Studies on Irrational Antibiotic/Antibacterial Drugs Use in Various Healthcare Settings and Communities, and Their Impact in Developing Countries}

The intervention studies to improve $A B$ drug use in developing countries were identified and retrieved. All studies that contained both quantitative and qualitative data were included. The following study characteristics were noted including intervention type, study design, geographical location, target group, study setting and effect and effect size were noted. The interventions used included education, managerial, regulatory, diagnostic, economic/financial and their subcategories as well as the multifaceted/multi-interventions [17-20]. They were selected because of their wide use internationally $[1,3,18$, $19,32,43]$. The target groups included prescribers, nurses, pharmacists, dispensers, hospital managers and the communities since they were involved in the handling of these drugs. The settings included hospitals, outpatient departments, public health facilities, private pharmacies/drug stores and the communities. The outcome measures were prescribing practices and behavior, antibiotic/antibacterial use, effective management of bacterial resistance cases and emergence of bacterial resistance as well as the cost of the drugs.

\subsection{Criteria for Inclusion and Exclusion of Studies in the Review}

The following four components of an answerable review question, PICO were used in this review including 1) the patient, population, or problem (P); 2) the intervention, independent variable, or exposure (I); 3) the comparators (C); and 4) the dependent variables or outcomes of interest (O) [58,60-64]. Also an additional component the study design (S) was added to limit the systematic review to certain types of studies, such as cohort studies. However there were variations in PICOS that existed in literature, such as one that adds a " $\mathbf{D}$ " for study design (PICO-D) and one that incorporates a "T" for timing and an "S" for setting (PICO-DTS) [60-63]. All the studies included in the review followed PICO-DTS. This was because it incorporated the study timing and the study setting which were important in the review process on irrational antibiotics/antibacterial use in various healthcare facilities in developing countries. The inclusion criteria of the study in the review process followed the PICO-DTS as follows:

\subsubsection{Population (P)}

- Any individual who handles officially and unofficially (prescribers or dispenses) antibiotics/antim- icrobials as a way of prescribing and dispensing.

- Any administrators involved in procurement, selection and distribution of the antibiotics/antibacterial drugs.

- Anyone involved in the regulation of antibiotics/antibacterial drugs at national, health facilities and the community.

- All the patients who can consent since they can be able to provide the informed information on the use of antibiotics/antibacterial drugs and their use unaided.

- Communities and general public

- All the people both adults and children involved in the studies were considered. The children should have got the consent from the parents or guardians [65-67].

\subsubsection{Intervention (I)}

The intervention measures to be identified in various studies and literature were standard interventions as described above and were evaluated for each study on their effect on antibiotic/antibacterial drug misuse and inappropriate use. They are recommended by the World Health Organization and the Management Science for Health [17-20].

\subsubsection{Comparison or Comparator (C)}

- All studies involving the use of two groups (1) any interventions outlined above and (2) the control or randomized controlled trials (RCTs) as well as prospective studies and time series were included. The relevant unpublished studies (gray studies) were also retrieved and included in the review.

\subsubsection{Outcome Measures (O)}

1) Primary outcome measures

The primary outcome measures that were evaluated for any intervention measure on antibiotic/antibacterial misuse in developing countries that were included in the review were quantitative measures (percentage, ratio and numbers). Among these included the percentage (\%) increase or reduction in antibiotic/antibacterial drug use, \% belief of $\mathrm{AB}$ use; \% $\mathrm{AB}$ prescriptions in infections such as diarrhea, viral infections (flu), scabies, surgeries, deliveries, malaria, sexually transmitted diseases; \% use of $\mathrm{AB}$ in acute respiratory tract infections, \% correct use of $\mathrm{AB}, \%$ adherence to $\mathrm{AB}$ use, \% use of $\mathrm{AB}$ in resistant bacterial diseases, \% use of $\mathrm{AB}$ for prophylaxis, $\% \mathrm{AB}$ use in restriction cases, $\% A B$ indications, $\% A B$ use rate, \% inappropriate $A B$ use, \% incidence of methicillin resistant Staphylococcus aureus (MRSA), \% AB use after diagnostic test and the cost of treatment of bacterial 
infections as well as the \% AB use a given period of interventions.

2) Secondary outcome measures

The secondary outcome measures included in the study were the reduction in the emergence of resistance, cost of treatment of bacterial diseases, polypharmacy, adverse drug reactions (ADRs), death and many others. The other outcome measure qualitatively, on the irrational $\mathrm{AB}$ drug use included reduction/decrease or improvement/increase). The effect and effect size were reported as a \% reduction/decrease or improvement/ increase in the outcomes of the intervention that were noted.

\subsubsection{Study Designs (S)}

The following studies were included in the review:

- Before and after studies using controls

- Before and after studies without controls

- Retrospective studies using controls

- Retrospective studies without controls

- Both the published and unpublished work

\subsubsection{Time and Place (T)}

- Studies that were included were from 1985-2010. The period was chosen in order to find out whether there were current intervention studies that were conducted to address the current concern of inappropriate and misuse of the antibiotic/antibacterial drugs and their impact in tackling the observed increment in resistance to the most common bacteria.

- Studies were from developing countries from low income, middle income to upper middle income as per the classification of the Organization for Economic Co-operation and Development (OECD) and World Bank membership guide [68,69].

\subsection{Exclusion Criteria}

Studies were excluded on the following grounds:

- All studies that didn’t involve antibiotic/antibacterial drugs or agents.

- All studies done outside developing countries

- All studies with flaw, wrongly designed and wrong data analysis.

- Studies that didn't attempt to measure the impact of the intervention

- Studies that lacked geographical location of where it was conducted

\subsection{Quality of Evidence}

The quality of evidence from the retrieved studies was judged by appraising of individual primary research studies [70-72] and the following criteria was used.

\section{Appraisal of Individual Primary Research \\ Studies for Inclusion in Reviews}

There are many approaches that have been reported to be used in assessing quality of the studies and these vary depending upon the type of research design concerned. Also there are a large number of published quality appraisal tools which are concerned with the issue of trustworthiness of the studies in them with little reference to the review question [70-73]. In addition, the relevance of aspects of individual studies for answering the review question may be considered when appraising their potential contribution to a review's conclusions. The other one is the 'review specific assessments' which is a consideration of the appropriateness of the methodology used in an individual study for answering the reviews question. Several different study designs may be included in the synthesis, with some being more appropriate than others [70-73]. Then the "review specific" in which assessment was in terms of the relevance of focus of individual studies in relation to the review question, such as differences in topic focus, population focus or setting. The following three sets of criteria of judgments were used in this review and the method of quality assessment in this review was adopted from Gough, 2007 [70-73] as shown below.

A = The trustworthiness of the results judged by the quality of the study within the accepted norms for undertaking the particular type of research design used in the study (Methodological quality).

$\mathbf{B}=$ The appropriateness of the use of that study design for addressing the systematic review's research question (Methodological relevance).

$\mathbf{C}=$ The appropriateness of focus of the research for answering the review question. (Topic relevance).

D = Judgment of overall weight of evidence (WoE) based on the assessments made for each of the criteria A-C.

Each of the studies was assessed either as follows [74]:

- High: Further research is very unlikely to change our confidence in the estimate of effect. ++++

- Moderate: Further research is likely to have an important impact on our confidence in the estimate of effect and may change the estimate. +++

- Low: Further research is very likely to have an important impact on our confidence in the estimate of effect and is likely to change the estimate. ++

- Very low: Any estimate of effect is very uncertain. + Or

By using the scale below [73,75,76]:

- 1-Strongly Agree 5-Agree 10-Disagree or using Yes (Y) or No (N) or Not applicable (NA)

However, in this review, the first one was used because it was convenient. The composite result of taking 
into account all the assessments on all the above three criteria was used to summarize the "weight of evidence" each study can contribute to the review's findings [71]. However, for some reviews it was appropriate to use just one or two of the criteria, for example if there was little variability in the study designs, or in the focus of the studies. This method was chosen to determine the quality of evidence of the primary data unlike other methods because 1) several studies may have different study designs and therefore this method can allow the inclusion of such different studies in the data synthesis [70-72]; 2) it allows assessment of the methodological quality that determines the trustworthiness of the results; 3 ) it allows the assessment of the methodological relevance to the research question and this show how appropriate the study design was; 4) it also allows the assessment of the topic relevance to the research question; and 5) finally this method is able to work out the overall weight of evidence of 1), 2), 3) and 4) of the primary studies. All other methods for evaluating the quality of the primary studies may not take into account the total weight of the study unlike this method chosen. Secondly, it is not specific to a particular study design and because of this it allows all articles with different study designs to be evaluated. It also assesses and relates the research question, study design and the output (results) in a systematic way and it is simple to use unlike other methods.

\subsection{Data Extraction and Storage from the Primary Data}

Data was extracted using the designed data extraction sheet basing on the aims of the review criteria such as:

- Geographical location of where the study was con- ducted

- Categories and subcategories of the intervention

- Study settings

- Outcome measure basing on the effect and the effect size on antibiotic/antibacterial misuse

\subsection{Data Synthesis and Analysis}

For further quality assessment of the primary data of the retrieved articles, two reviewers independently assessed each study as per the inclusion criteria and a total of 55 primary studies were judged to be included in the review process on the intervention effects of irrational $A B$ drugs use in the developing countries or poor nations $[77,78]$.

\section{RESULTS}

The results show that 722 potentially relevant primary studies on irrational $\mathrm{AB}$ drugs use in the developing countries or poor nations were identified and screened for inclusion in the review. Six hundred and twenty (620) studies were excluded on the basis of lack of geographical location, no study setting, did not involve $A B$ and they lacked suitable study design or intervention and year of publication within 10 years as set in the inclusion criteria. One hundred and two (102) studies were further evaluated for inclusion in the study and of these 47 studies were excluded due to the following reasons: lack of outcome measure, non-human subjects were used in the study, it was a review study, no randomization or no methods described in the study, lack of study design, lack of controls or comparators, retrospective study. After evaluation of the studies, a total of 55 studies were included in the systematic review process (Figure 1).

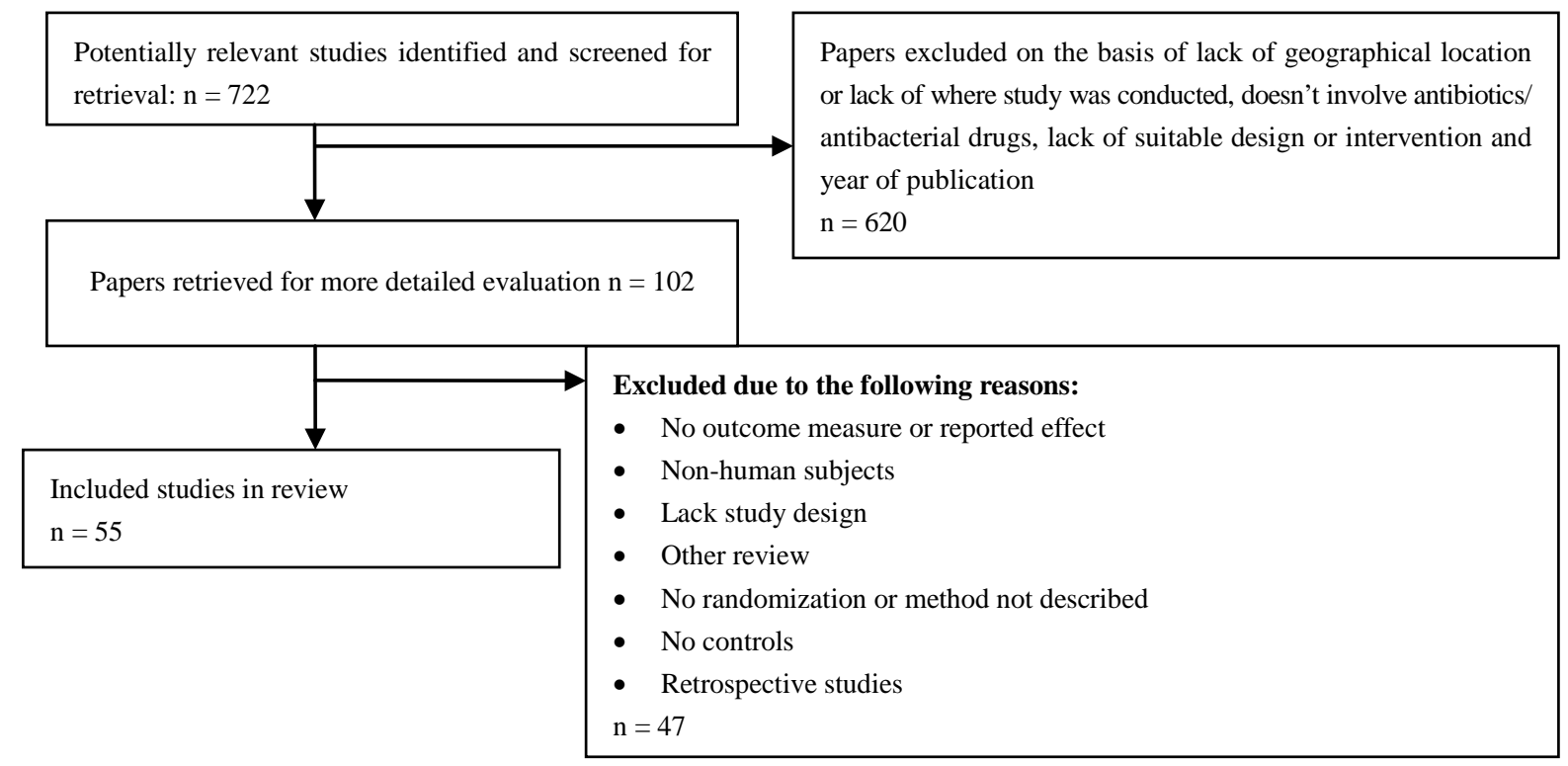

Figure 1. Summary of the included and excluded primary studies in the review process. 
Of the 55 studies included in the systematic review, $10.9 \%(n=6)$ were from Africa, 63.6\% $(n=35)$ were from Asia, 9.1\% $(n=5)$ from Latin America and 16.4\% $(n=9)$ were from South-eastern Europe (Table 2). The education intervention measure contributed $29.0 \%$ ( $\mathrm{n}=$ 16), managerial had $20.0 \%(\mathrm{n}=11)$, economic /financial intervention had no study, regulatory had 7.8\% $(n=5)$, diagnostic and education-managerial intervention meas- ure had 3.6\% $(\mathrm{n}=2)$ respectively, education-regulatory had $9.0 \%(n=5)$ and multi-faceted intervention measure had $27.0 \%(n=15)$. For the study setting, hospitals had $52.7 \%(n=29)$, outpatients had 5.5\% $(n=3)$, public health facilities had $21.8 \%(\mathrm{n}=12)$, private pharmacies/drug stores had $12.7 \%(n=7)$ and the community studies had 7.3\% $(n=4)$ (Table 3$)$.

The effect of education intervention after discussion,

Table 2. Geographical distribution of the different interventions studies on antibiotics/antibacterial use in the various study settings.

\begin{tabular}{|c|c|c|c|c|c|c|c|}
\hline \multirow[b]{2}{*}{ Region } & \multirow[b]{2}{*}{ Intervention } & \multicolumn{6}{|c|}{ Study setting } \\
\hline & & Hospital & Outpatient & Public facilities & $\begin{array}{c}\text { Private Pharmacies/ } \\
\text { drug stores }\end{array}$ & Community & Total \\
\hline \multirow{7}{*}{ Africa } & Education & 0 & 0 & $1[55]$ & 0 & $1[50]$ & 2 \\
\hline & Managerial & 0 & 0 & $1[9]$ & 0 & 0 & 1 \\
\hline & Economic & 0 & 0 & 0 & 0 & 0 & $\mathbf{0}$ \\
\hline & Regulatory & 0 & 0 & 0 & 0 & 0 & $\mathbf{0}$ \\
\hline & Diagnostic & 0 & 0 & 0 & 0 & 0 & $\mathbf{0}$ \\
\hline & Education-managerial & $1[6]$ & 0 & $1[49]$ & 0 & 0 & 2 \\
\hline & Education-regulatory & 0 & 0 & 0 & 0 & 0 & $\mathbf{0}$ \\
\hline \multirow{3}{*}{ Total } & Multi-faceted & 0 & 0 & $1[1]$ & 0 & 0 & 1 \\
\hline & & 1 & $\mathbf{0}$ & 4 & $\mathbf{0}$ & 1 & $6(10.9 \%)$ \\
\hline & Education & $5[16,31,46,65,79]$ & 0 & $2[23,25]$ & $2[15,28]$ & 1 [18] & 10 \\
\hline \multirow{6}{*}{ Asia } & Managerial & $4[54,57,80,81]$ & 0 & $1[42]$ & 0 & 0 & 5 \\
\hline & Economic & 0 & 0 & 0 & 0 & 0 & 0 \\
\hline & Regulatory & $1[17]$ & 0 & 0 & 0 & $1[56]$ & 2 \\
\hline & Diagnostic & 0 & $1[51]$ & 0 & 0 & 0 & 1 \\
\hline & Education-managerial & 0 & 0 & 0 & 0 & 0 & 0 \\
\hline & Education-regulatory & $1[2]$ & 0 & $1[43]$ & $2[60,61]$ & 0 & 4 \\
\hline \multirow{3}{*}{ Total } & Multi-faceted & $8[4,7,8,11,14,26,30,67]$ & 0 & $3[24,58,66]$ & $2[13,62]$ & 0 & 13 \\
\hline & & 19 & 1 & 7 & 6 & 2 & $35(63.6 \%)$ \\
\hline & Education & 0 & 0 & 0 & 0 & 0 & 0 \\
\hline \multirow{6}{*}{$\begin{array}{c}\text { Latin } \\
\text { America }\end{array}$} & Managerial & $2[29,63]$ & $1[20]$ & 0 & 0 & 0 & 3 \\
\hline & Economic & 0 & 0 & 0 & 0 & 0 & 0 \\
\hline & Regulatory & 0 & 0 & 0 & $1[22]$ & 0 & 1 \\
\hline & Diagnostic & 0 & 0 & 0 & 0 & 0 & 0 \\
\hline & Education-managerial & 0 & 0 & 0 & 0 & 0 & 0 \\
\hline & Education-regulatory & 0 & 0 & 0 & 0 & 0 & 0 \\
\hline \multirow{3}{*}{ Total } & Multi-faceted & $1[3]$ & 0 & 0 & 0 & 0 & 1 \\
\hline & & 3 & 1 & $\mathbf{0}$ & 1 & $\mathbf{0}$ & $5(9.1 \%)$ \\
\hline & Education & 0 & $1[5]$ & $1[64]$ & 0 & 1 [19] & 3 \\
\hline \multirow{6}{*}{$\begin{array}{l}\text { South-Eastern } \\
\text { Europe }\end{array}$} & Managerial & $2[52,82]$ & 0 & 0 & 0 & 0 & 2 \\
\hline & Economic & 0 & 0 & 0 & 0 & 0 & 0 \\
\hline & Regulatory & $2[83,84]$ & 0 & 0 & 0 & 0 & 2 \\
\hline & Diagnostic & 1 [32] & 0 & 0 & 0 & 0 & 1 \\
\hline & Education-managerial & 0 & 0 & 0 & 0 & 0 & 0 \\
\hline & Education-regulatory & $1[53]$ & 0 & 0 & 0 & 0 & 1 \\
\hline \multirow{3}{*}{ Total } & Multi-faceted & 0 & 0 & 0 & 0 & 0 & 0 \\
\hline & & 6 & 1 & 1 & $\mathbf{0}$ & 1 & $9(16.6 \%)$ \\
\hline & and total & $29(52.7 \%)$ & $3(5.5 \%)$ & $12(21.8 \%)$ & $7(12.7 \%)$ & $4(7.3 \%)$ & $55(100 \%)$ \\
\hline
\end{tabular}

Key: [] denotes the cited reference of the article as it appears in the reference section. 
showed that there was $-19.2 \%$ mean reduction in $A B$ use and $\mathrm{a}-40.1 \%$ belief of unnecessary use of $\mathrm{AB}$. There was a $-27.6 \%$ mean reduction of $\mathrm{AB}$ use in severe infections, $-1.1 \% \mathrm{AB}$ use in the mild infections and $+1.0 \%$ increase in number of non-prescription of $A B$ to the patients (Table 4).

For the education interventions on $\mathrm{AB}$ drug use after community trainings, results show that there was a $-30.5 \%$ reduction in $\mathrm{AB}$ use, $-23.8 \%$ mean reduction in $\mathrm{AB}$ prescription in severe infections, $-1.0 \%$ in mild infections and $-5.0 \%$ reduction in non-prescription of $A B$ drugs. There was a $-18.5 \%$ reduction in the use of $A B$ in acute respiratory tract infections (ARI) and a $-16.0 \%$ in mild
ARI. There was a $-56.8 \%$ reduction in use of $A B$ in diarrhea and a $-36.0 \%$ belief of unnecessary $A B$ use (Table 5).

The managerial interventions on $\mathrm{AB}$ use, the results show that there were $+8.0 \%$ improvements in the use of the correct dose of $\mathrm{AB}$ drugs and $+54.0 \%$ improvements in adherence to the $\mathrm{AB}$ drug treatments. There was $-31.8 \%$ eduction in $\mathrm{AB}$ received at the various health facilities. The results also show that there was $+29.1 \%$ mean increment in $\mathrm{AB}$ use against resistant cases. It also show that, there was a $+54.8 \%$ increment in prophylactic $A B$ use (Table 6).

For the regulatory intervention measure on $\mathrm{AB}$ use, the

Table 3. Distribution of the various intervention studies on antibiotics/antibacterial use in the different study settings.

\begin{tabular}{|c|c|c|c|c|c|c|}
\hline \multirow{2}{*}{ Intervention studies } & \multicolumn{6}{|c|}{ Study setting } \\
\hline & Hospitals & Outpatients & Public facilities & Private Pharmacies /drug stores & Community & Total \\
\hline Education & 5 & 1 & 4 & 2 & 4 & $16(29.0 \%)$ \\
\hline Managerial & 8 & 1 & 2 & 0 & 0 & $11(20.0 \%)$ \\
\hline Economic & 0 & 0 & 0 & 0 & 0 & $0(0 \%)$ \\
\hline Regulatory & 3 & 0 & 0 & 1 & 0 & $4(7.8 \%)$ \\
\hline Diagnostic & 1 & 1 & 0 & 0 & 0 & $2(3.6 \%)$ \\
\hline Education-managerial & 1 & 0 & 1 & 0 & 0 & $2(3.6 \%)$ \\
\hline Education-regulatory & 2 & 0 & 1 & 2 & 0 & $5(9.0 \%)$ \\
\hline Multi-faceted & 9 & 0 & 4 & 2 & 0 & $15(27.0 \%)$ \\
\hline Total & $29(52.7 \%)$ & $3(5.5 \%)$ & $12(21.8 \%)$ & 7 (12.7\%) & $4(7.3 \%)$ & $55(100 \%)$ \\
\hline
\end{tabular}

Table 4. Effects of education interventions on antibiotic/antibacterial drug use after discussion.

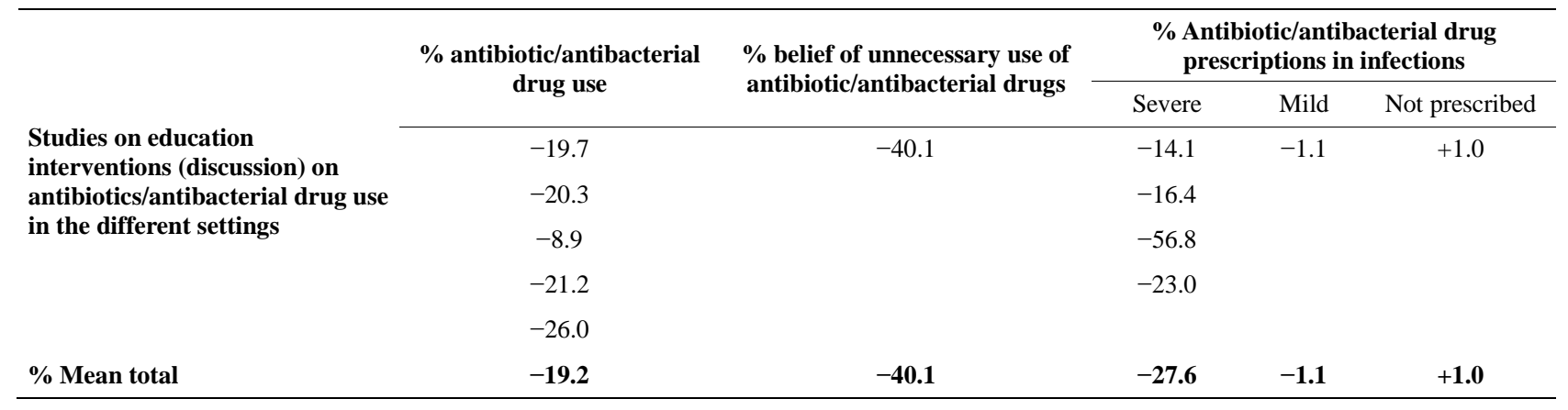

Key: + increase; - reduction.

Table 5. Effects of education interventions on antibiotic/antibacterial (AB) drug use after community trainings.

\begin{tabular}{|c|c|c|c|c|c|c|c|c|}
\hline \multirow{5}{*}{$\begin{array}{l}\text { Studies on AB use } \\
\text { after community } \\
\text { training }\end{array}$} & \multirow{2}{*}{$\%$ AB use } & \multicolumn{3}{|c|}{$\%$ AB prescriptions in infections } & \multicolumn{2}{|c|}{$\begin{array}{c}\text { \% use of } \mathrm{AB} \text { in acute respiratory } \\
\text { tract infections (ARI) }\end{array}$} & \multirow{2}{*}{$\begin{array}{l}\text { \% AB use in } \\
\text { diarrhea }\end{array}$} & \multirow{2}{*}{$\begin{array}{c}\% \text { belief of } \\
\text { unnecessary } \\
\text { AB use }\end{array}$} \\
\hline & & Severe & Mild & Not prescribed & Acute & Mild & & \\
\hline & -30.5 & -21.0 & -1.0 & -5.0 & -21.0 & -30.5 & -56.8 & -34.0 \\
\hline & & -28.5 & & & -16.4 & -1.0 & & -38.0 \\
\hline & & & & & -23.0 & & & \\
\hline$\%$ Mean total & -30.5 & -23.8 & -1.0 & -5.0 & -18.5 & -16.0 & -56.8 & -36.0 \\
\hline
\end{tabular}

Key: - reduction. 
Table 6. Effects of managerial interventions on antibiotic/antibacterial (AB) drug use.

\begin{tabular}{|c|c|c|c|c|c|c|}
\hline & \multirow{2}{*}{$\begin{array}{l}\begin{array}{c}\% \text { use of } \\
\text { correct dose }\end{array}\end{array}$} & \multirow{2}{*}{$\%$ adherence } & \multirow{2}{*}{$\% \mathrm{AB}$ received } & \multirow{2}{*}{$\begin{array}{l}\% \text { use of } A B \text { in } \\
\text { resistant cases }\end{array}$} & \multicolumn{2}{|c|}{$\%$ AB use in prophylaxis } \\
\hline & & & & & Necessary & Not necessary \\
\hline & +8.0 & +8.0 & -10.6 & +39.0 & 0.0 & +9.8 \\
\hline & & +100.0 & -6.4 & -16.6 & & +100.0 \\
\hline \multirow{6}{*}{$\begin{array}{c}\text { Studies on } \\
\text { interventions on } \\
\text { AB use }\end{array}$} & & & -8.4 & +30.6 & & \\
\hline & & & -27.9 & +30.9 & & \\
\hline & & & -13.6 & +28.5 & & \\
\hline & & & -73.0 & & & \\
\hline & & & -83.0 & & & \\
\hline & & & -73.0 & & & \\
\hline$\%$ Mean total & +8.0 & +54.0 & -31.8 & +29.1 & 0.0 & +54.8 \\
\hline
\end{tabular}

results show that there was a $+60.6 \%$ mean increment on $\mathrm{AB}$ use restriction and $\mathrm{a}+16.4 \%$ increase in $\mathrm{AB}$ use with no restriction. However, there was also a $+34.2 \%$ mean improvement in appropriate AB use (Table 7).

The education/regulation intervention measure, results show that there was $-8.0 \%$ reduction in none $A B$ indication, $\mathrm{a}+24.0 \%$ improvement in $\mathrm{AB}$ use rate and $\mathrm{a}-14.5 \%$ mean appropriate $\mathrm{AB}$ use. There was a $-11.1 \%$ reductions in incidence of methicillin resistant Staphylococcus aureus (MRSA) bacterial organisms. There as a $-60.0 \%$ mean overall reduction in $\mathrm{AB}$ use at the health facilities. The results also show that there was a $-23.7 \%$ mean reduction in $\mathrm{AB}$ use against acute respiratory infections (ARI), and $\mathrm{a}-75.1 \%$ and $-42.4 \%$ reduction in $A B$ use in diarrhoea and scabies respectively (Table 8).

For the managerial/education intervention measure, there was $-4.7 \%$ mean reduction in $\mathrm{AB}$ drug prescription in the various healthcare facilities (Table 9).

For the diagnostic intervention, there was a $-68.0 \%$ reduction in $\mathrm{AB}$ use after diagnostic test as compared to $100 \% \mathrm{AB}$ use in the control group. The results also show that there was a $+73.0 \%$ likelihood of $\mathrm{AB}$ use after a positive diagnostic test as compared to the $+87.0 \%$ in the negative diagnostic test (Table 10).

For the multifaceted intervention measures that involved all the intervention measures (educational, managerial, diagnostic, regulatory and economic/financial measures), the results show that there was a $+63.0 \%$ improvement in $\mathrm{AB}$ use in the various healthcare facilities, $\mathrm{a}-2.6 \%$ mean reduction in the number of $\mathrm{AB}$ drug encounter and a $-23.0 \%$ reduction in $\mathrm{AB}$ prescription. There was also a $+18.3 \%$ improvement in generic $\mathrm{AB}$ prescription, a $-32.1 \%$ mean reduction in $A B$ use and a $-8.5 \%$ mean reduction in the cost of treatment of resistant organisms. The results also show a $-89.0 \%$ reduction in $A B$ use in ARI, a $-82.0 \%$ mean reduction in $A B$ use in surgery, a $-62.7 \%$ mean reduction in $A B$ use in deliveries, a $-14.7 \%$ mean reduction in $\mathrm{AB}$ use in malaria, a $-39.0 \%$ reduction in $\mathrm{AB}$ use in sexually trans- mitted diseases (STDs) and a $-36.3 \%$ mean reduction in AB use in diarrhoea (Table 11).

For some studies, the results showed that there was a $-6.3 \%$ reductions in mean $\mathrm{AB}$ encounters after 1 month of intervention and this then increased to $+7.7 \% \mathrm{AB}$ encounters after 3 months of intervention and hence lack of sustainability of intervention programme as observed in some studies (Table 12). There was no study on economic/financial intervention found for the systematic review in this study.

\section{DISCUSSION}

The review study show that AB drugs are irrationally used in various healthcare facilities globally especially in developing countries. They are among the most commonly used antimicrobial agents in the management of bacterial infections worldwide. The $\mathrm{AB}$ drugs belong to the class $\mathrm{B}$ drugs that are prescription only medicines (POM) but in most cases, these drugs are easily accessible in the communities, general public and the patients without prescription especially in the developing countries or poor nations where there is lack or weak regulation of the use of these medicines [31]. Even when the patients and the communities acquire the $A B$, they are not used appropriately. Also, in some cases the health workers (doctors, pharmacists and nurses) misuse these drugs by prescribing them inappropriately or irrationally especially in private health facilities where profit gain take precedence of the care and health of the individual patient [85]. On the other hand, self-medication in various communities in most countries is a problem where individuals use drugs or pharmaceutical products like $A B$, to treat self diagnosed disorders or symptoms or the intermittent or continued use of the medication prescribed by the physicians for a chronic or recurring diseases or symptoms [10]. It is currently an important issue that has greatly contributed to the emergence of global antimicrobial resistance to the available limited few and effective 
Table 7. Effects of regulatory interventions on antibiotic/antibacterial (AB) drug use.

\begin{tabular}{cccc}
\hline & \% AB use restriction & \% AB use with no restriction & \% appropriate AB use \\
\cline { 2 - 4 } Studies on interventions on AB use & +90.0 & +16.4 & +41.8 \\
& +30.2 & & +10.9 \\
\% Mean total & & +16.0 & +68.0 \\
\hline
\end{tabular}

Table 8. Effects of education/regulation interventions on antibiotic/antibacterial (AB) drug use.

\begin{tabular}{|c|c|c|c|c|c|c|c|c|}
\hline \multirow{6}{*}{$\begin{array}{c}\text { Studies on } \\
\text { interventions on } \\
\text { AB use }\end{array}$} & \multirow{2}{*}{$\begin{array}{c}\% \mathrm{AB} \\
\text { indication }\end{array}$} & \multirow{2}{*}{$\begin{array}{l}\% \text { AB use } \\
\text { rate }\end{array}$} & \multirow{2}{*}{$\begin{array}{c}\% \text { inappropriate } \\
\text { AB use }\end{array}$} & \multirow{2}{*}{$\begin{array}{l}\text { \% incidence } \\
\text { of MRSA }\end{array}$} & \multirow{2}{*}{$\begin{array}{c}\% \text { overall AB } \\
\text { use }\end{array}$} & \multicolumn{3}{|c|}{$\%$ AB use in infections } \\
\hline & & & & & & ARI & Diarrhea & Scabies \\
\hline & -8.0 & +24.0 & -22.0 & -14.5 & -60.0 & -33.6 & -75.1 & -42.4 \\
\hline & & & -5.0 & -12.0 & & -13.8 & & \\
\hline & & & -2.0 & -10.0 & & & & \\
\hline & & & & -8.0 & & & & \\
\hline$\%$ Mean total & -8.0 & +24.0 & -14.5 & -11.1 & -60.0 & -23.7 & -75.1 & -42.4 \\
\hline
\end{tabular}

Key: + increase; - reduction; MRSA-Methcillin-resistant Staphylococcus aureus.

Table 9. Effects of education/managerial interventions on antibiotic/antibacterial (AB) drug use.

\begin{tabular}{cc}
\hline \multirow{2}{*}{ Studies on interventions on AB use } & \% antibiotic/antibacterial (AB) drug prescriptions \\
\cline { 2 - 2 }$\%$ Mean total & -2.1 \\
& -7.2 \\
\hline
\end{tabular}

Key: - reduction.

Table 10. Effects of diagnostic intervention on antibiotic/antibacterial (AB) drug use.

\begin{tabular}{ccccc}
\hline \multirow{2}{*}{$\begin{array}{c}\text { Studies on diagnostic } \\
\text { interventions on } \mathrm{AB}\end{array}$} & $\begin{array}{c}\text { \% use of AB after } \\
\text { diagnostic test }\end{array}$ & $\begin{array}{c}\text { \% AB use in control } \\
\text { (no diagnostic test) }\end{array}$ & \multicolumn{2}{c}{ \% likelihood of AB use after diagnostic test } \\
\cline { 2 - 5 } & -68.0 & +100.0 & Positive test & Negative test \\
\% Mean total & $-\mathbf{6 8 . 0}$ & $+\mathbf{1 0 0 . 0}$ & +73.0 & +87.0 \\
\hline
\end{tabular}

Key: + increase; - reduction.

Table 11. Effects of multifaceted interventions on antibiotic/antibacterial (AB) drug use.

\begin{tabular}{|c|c|c|c|c|c|c|c|c|c|c|c|c|}
\hline & \multirow{2}{*}{$\begin{array}{c}\% \text { AB use } \\
\text { improvement }\end{array}$} & \multirow{2}{*}{$\begin{array}{c}\text { No. AB } \\
\text { encounters }\end{array}$} & \multirow{2}{*}{$\begin{array}{c}\% \text { AB } \\
\text { prescribed }\end{array}$} & \multirow{2}{*}{$\begin{array}{c}\text { \% generic } \\
\text { AB } \\
\text { prescribed }\end{array}$} & \multirow{2}{*}{$\begin{array}{c}\% \text { AB } \\
\text { use }\end{array}$} & \multirow{2}{*}{$\begin{array}{c}\% \text { cost of } \\
\text { treatment } \\
\text { of resistant } \\
\text { organisms }\end{array}$} & \multicolumn{6}{|c|}{$\%$ use of $\mathrm{AB}$ in microbial infections } \\
\hline & & & & & & & ARI & Surgery & Delivery & Malaria & STD & Diarrhea \\
\hline & +63.0 & +1.4 & -23.0 & +18.3 & -23.0 & -11.0 & -89.0 & -87.0 & -85.0 & -10.0 & -39.0 & -59.0 \\
\hline \multirow{6}{*}{$\begin{array}{c}\text { Studies on } \\
\text { multifaceted } \\
\text { AB use }\end{array}$} & & +2.6 & & & -17.0 & -6.0 & & -77.0 & -64.0 & -11.0 & & -33.0 \\
\hline & & -3.9 & & & -13.0 & & & & -67.0 & -17.0 & & -17.0 \\
\hline & & -4.3 & & & -59.0 & & & & -37.0 & -20.0 & & \\
\hline & & -2.6 & & & -48.1 & & & & -23.0 & -15.0 & & \\
\hline & & -3.2 & & & & & & & -100.0 & & & \\
\hline & & -0.3 & & & & & & & & & & \\
\hline$\%$ Mean total & +63.0 & -2.6 & -23.0 & +18.3 & -32.1 & -8.5 & -89.0 & -82.0 & -62.7 & -14.7 & -39.0 & -36.3 \\
\hline
\end{tabular}

Key: + increase; - reduction; ARI—acute respiratory infections; STD—sexually transmitted diseases (infections). 
Table 12. Effects of antibiotic/antibacterial (AB) drug use after intervention with time.

\begin{tabular}{ccc}
\hline & \multicolumn{2}{c}{ \% AB use in a given period of time after intervention } \\
\cline { 2 - 3 } Studies on AB use with time after & 1 month after intervention & 3 months after intervention \\
\cline { 2 - 3 } & -6.3 & +7.7 \\
\% Mean total & -6.3 & +7.7 \\
\hline
\end{tabular}

antibiotics/antibacterial drugs. The emergence of antibacterial resistance has significantly contributed to the high cost of treatment of the resistant bacterial infections, exposure to the second and third-line drugs like for the case of the multi-drug resistant tuberculosis (MDR-TB) and extended-drug resistant tuberculosis (XDR-TB) such as aminoglycosides and fluoroquinolones which requires prolonged treatment with the drugs and also which are not only expensive, but also highly toxic to the patients [75,76]. The individual patients may also experiences prolonged hospitalization, suffering and sometimes death.

However, because of these challenges of irrational AB use, many intervention measures including education to persuade and inform all the stakeholders on the rational use of medicines, managerial to structure decisions on proper use of medicines, provision of diagnostic tools and laboratories to ensure that there is diagnostic confirmation of bacterial infections and then prescribe the right medications, regulation to restrict decisions such that health workers prescribe drugs within the regulatory framework and also the patients and communities are restricted in the access of such medicines like the $A B$, as well as economic/financial restrictions such that the health facilities only purchases medicines required by the majority of the population in the various communities [3,4,16-20,86,87]. However, despite of all the efforts to institute the intervention measures on $A B$ use in both the developed and developing nations, irrational $A B$ use and increased emergence of resistance continues to be a global problem with no boundary restrictions.

However because of these challenges, some countries and regions of the world are taking irrational $A B$ use a serious problem and review results show the Asian countries conducted more intervention studies on $\mathrm{AB}$ use as a way to promote rational $\mathrm{AB}$ use among health workers in the various health care facilities and the communities and hence reduce the emergence of resistant bacterial infections and cost of treatment. The review results also showed that African, Latin American and south-eastern Europe regions had the fewest intervention studies on irrational $\mathrm{AB}$ use and this could possibly be due to the lack of will from various governments to combat the problem, poor or weak non- functional regulatory authorities as well as the increased levels of corruption in most of these countries especially in most countries of sub-Saharan Africa as opposed to the Asian, Europe and north American countries. The poor and lack of healthcare services in various communities of the developing countries have also promoted the irrational AB use.

The review also show that most of the studies were done mainly in hospitals where there is ease of access and monitoring of medicines use as opposed to the pharmacies and drug shops and communities where possibly serious irrational $A B$ use is practiced. The lack of resources in terms of human and financial resource could have been a limiting factor to carry out the interventions in such areas and hence remaining a great factor in promoting irrational $\mathrm{AB}$ use. The lack of information among the population on the associated dangers of irrational $A B$ use and the burden of the increased emergence of antibacterial resistance is also a serious problem [30].

The review also showed that whereas the educational, managerial, diagnostic, regulatory, economic/financial intervention measures individually can influence the behavior of healthcare workers on rational AB use, but they could still not offer a sustainable change and therefore multi-faceted intervention measures where a multi-approach intervention measures were applied at the same time showed a great improvement and promoted rational $\mathrm{AB}$ use among healthcare workers, healthcare facilities and the communities $[40,41,88]$. This approach involved combination of persuasion and giving information on rational $\mathrm{AB}$ use, structure decisions on proper use of medicines, provision of diagnostic tools and laboratories and restriction on drugs to be used and within the regulatory framework. Also the patients and communities were possibly educated on the proper use of $\mathrm{AB}$ and also informing them that not all disease conditions such as acute respiratory tract infections [7,27,28,89], diarrhea [29], scabies, flu [25], malaria [22], viral infections, deliveries and surgeries [90] and many others requires $A B$ $[7,22,28]$ and this changes a belief where many people think that any disease condition requires a pill [27]. This greatly changes the thinking, behaviors and belief among the patients, general public and the communities on the proper use of $\mathrm{AB}$ and hence the seeking behavior of the individuals of these medicines and hence the habit of self-medication with antimicrobial drugs especially the $\mathrm{AB}[15,37,38,41,83,85]$. Also the restriction in the access of such medicines like the $\mathrm{AB}$ showed to offer improvement on rational $\mathrm{AB}$ use especially in the Asian region as opposed to African, Latin America and south-eastern Europe [3,4]. 
However, something interesting was observed in the review process where the intervention measures do not offer a sustainable and life long change or continuous improvement in rational $\mathrm{AB}$ use (Table 12). The results showed that after 1 month there was improvement in $A B$ use but after 3 months the situation reverted or worsened thus showing lack of sustainability of the intervention measures in the improvement of $\mathrm{AB}$ use in various healthcare facilities and the communities. The change in $\mathrm{AB}$ use over the time could have been due to the drug explosion in which there was an increase in the number of drugs available and thus complicates the choice of appropriate drug for particular indication. Also the patients demands and the satisfaction of their expectations and demands of quick relief, clinician prescribe a drug for every single complaint and this has led to a belief that "every ill has a pill" this contributing to the polypharmacy [27]. The lack of up to date unbiased information on the currently available and used drugs poses a problem where majority of practitioners rely on medical representatives who have interest in specific medications. The faulty and the inadequate clinical training and education of medical graduates may be a problem where health workers especially doctors depends on diagnostic aid, rather then clinical diagnosis, a problem that is on rise everyday passes. Poor communication between health professional and the patients may also be a problem where less time to the patient is given and no explanation to some basic information about the use of drugs is provided. The lack of diagnostic facilities and the uncertainty of diagnosis to make a proper diagnosis is an important step toward rational drug therapy and therefore healthcare facilities especially in rural areas of developing countries face a lot of difficulty in reaching to a precise diagnosis due to non availability of diagnostic facilities and thus promoting polypharmacy. The defective drug supply system and weak or ineffective drug regulation contributes to the presence of high number of drugs in the market leads to irrational use of drugs. The increased medical representatives and the lucrative promotional programmes of the various pharmaceutical industries greatly influence the drug prescribing and hence promoting rational $\mathrm{AB}$ use $[3,4,27,89]$.

This therefore calls for a continuous implementation of multi-faceted intervention measures over prolonged period of time in the various healthcare facilities such that it become a routine procedure to all stakeholders handling $\mathrm{AB}$. Also the irrational drug use should be incorporated in the medical curriculum and emphasized in the medical schools. The interventions in form of continuous medical education (CME) [86] should also be extended to the communities and the general public since self-medications with various medications especially $A B$ are a common practice.

\section{CONCLUSION}

Irrational $\mathrm{AB}$ use is a common problem globally especially in developing countries where intervention studies were conducted. Many studies on intervention measures were used to control irrational drug use and many of them were conducted in Asia region with few done in Africa, Latin America and South-Eastern Europe. Most of the studies were done in hospitals and little in pharmacies, drug shops where the general public and communities receives the $\mathrm{AB}$ drugs and in the general public and communities. Most of the studies showed an improvement in $A B$ use with the most significant improvement observed with the multi-faceted intervention measure. However, the intervention measures were not able to offer a sustainable and continuous improvement in rational drug use for a prolonged period of time since after some time the progress on promoting rational $A B$ use soon changed to irrational or reverted to the previous situation prior to the instituting of the intervention measures. Therefore irrational $\mathrm{AB}$ use is a serious problem in developing countries and so instituting of multi-faceted intervention measure in various healthcare facilities, healthcare workers, general public and in the communities for a prolonged period of time in form of continuous medical education can offer a sustainable promotion of rational $\mathrm{AB}$ use and thus reduce the emergence of antibacterial resistance, cost of treatment, prolonged hospitalization and some cases deaths.

\section{ACKNOWLEDGMENTS \& SOURCE OF FUNDING}

Acknowledge goes to the Common Wealth Scholarship programme \& staffs of University of London, Department of Primary Care \& Population Health (PCPH) for their support especially Prof. Petra Boyton, Prof. Ceri Butler, Prof. Trish Greenhalgh \& others.

\section{SOURCE OF FUNDING}

Common Wealth Scholarship Programme and University College London, Department of Primary Care and Population Health (PCPH).

\section{RUNNING TITLE}

Review of intervention measures on irrational antibiotic use in developing nations.

\section{REFERENCES}

[1] Kardas, P., Devine, S., Golembesky, A. and Roberts, C. (2005) A systematic review and meta-analysis of misuse of antibiotic therapies in the community. International Journal of Antimicrobial Agents, 26, 106-113. http://dx.doi.org/10.1016/j.ijantimicag.2005.04.017

[2] Holloway, K. (2005) Rational use of drugs: An overview, 
technical briefing seminar. World Health Organization, Geneva.

[3] MSH (1997) Managing for rational drug use: Managing drug supply. Management Science for Health (MSH) in collaboration with the World Health Organization Action Programme on Essential Drugs. 2nd Edition, Kumarian Press, Sterling, 421-429.

[4] WHO (2010) Rational use of medicines. World Health Organization (WHO)/Rational use of Medicines. http://wwwwhoint/medicines/areas/rational use/en/

[5] Hawkey, P.M. (2008) The growing burden of antimicrobial resistance. Journal of Antimicrobial Chemotherapy, 62, i1-i9. http://dx.doi.org/10.1093/jac/dkn241

[6] Larson, E. (2007) Community factors in the development of antibiotic resistance. Annual Review of Public Health, 28, 435-447.

http://dx.doi.org/10.1146/annurev.publhealth.28.021406.1 $\underline{44020}$

[7] Ong, S., Nakase, J., Moran, G.J., Karras, D.J., Kuehnert, M.J. and Talan, D.A. (2007) Antibiotic use for emergency department patients with upper respiratory infections: Prescribing practices, patient expectations, and patient satisfaction. Annals of Emergency Medicine, 50, 213-220. http://dx.doi.org/10.1016/j.annemergmed.2007.03.026

[8] Slama, T.G., Amin, A., Brunton, S.A., et al. (2005) A clinician's guide to the appropriate and accurate use of antibiotics: The Council for Appropriate and Rational Antibiotic Therapy (CARAT) criteria. American Journal of Medicine, 118, 1S-6S. http://dx.doi.org/10.1016/j.amjmed.2005.05.007

[9] WHO (2006) The role of education in the rational use of medicines. SEARO Technical Publication Series No 45, World Health Organization, Regional Office for SouthEast Asia, New Delhi, 1-101.

[10] Widayati, A., Suryawati, S., De Crespigny, C. and Hiller, J.E. (2011) Self medication with antibiotics in Yogyakarta City Indonesia: A cross sectional population-based survey. BMC Research Notes, 491. http://dx.doi.org/10.1186/1756-0500-4-491

[11] Web definitions for antibiotic. (2010) www.wordnetwebprincetonedu/perl/webwn

[12] Brunton, L.L., Lazo, J.S. and Parker, K.L. (2006) General principles of antimicrobial therapy: Chemotherapy of microbial diseases. In: Goodman \& Gilman's The Pharmacological Basis of Therapeutics, 11th Edition, McGrawHill Publishers, 1095-1154.

[13] FAO (2005) Responsible use of antibiotics in aquaculture. FAO Fisheries Technical Paper 469, Food and Agricultural Organization (FAO) of the United Nations, Rome, $1-110$. ftp://ftp.fao.org/docrep/fao/009/a0282e/a0282e00.pdf

[14] MSH (1997) The selection, procurement, distribution and use of pharmaceuticals: Managing drug supply-Promoting rational prescribing. Management Science for Health (MSH) in collaboration with the World Health Organisation Action Programme on Essential Drugs, 2nd Edition, Kumarian Press, Sterling, 465-511.

[15] Smith, L.A., Jones, C., Meek, S. and Webster, J. (2009) review: Provider practice and user behavior interventions to improve prompt and effective treatment of malaria: Do we know what works? American Journal of Tropical Medicine and Hygiene, 80, 326-335.

[16] WHO (2003) Report on consultation meeting on improving access to essential medicines in the Western Pacific Region. Penang, Malaysia. World Health Organization Regional Office for the Western Pacific Manila, Philippines, 1-44.

[17] WHO (2006) The role of education in the rational use of medicines. SEARO Technical Publication Series No. 45, World Health Organization, Regional Office for SouthEast Asia, New Delhi, 1-101.

[18] MSH (1997) Promoting rational prescribing. Management Science for Health (MSH) in collaboration with the World Health Organization Action Programme on Essential Drugs. 2nd Edition, Kumarian Press, Sterling, 464482.

[19] WHO (2002) Promoting rational use of medicines: Core components. WHO/ EDM/20023, 5 (Paper 1), WHO Policy Perspectives on Medicines World Health Organization, Geneva, 1-6.

http://apps.who.int/medicinedocs/pdf/h3011e/h3011e.pdf

[20] WHO (2003) Essential Drugs and Medicines Policy: Access to quality essential medicines is the right of every patient. WHO Regional Office for the Western Pacific WPRO-EDM, II (1), 1-12.

http://wwwwprowhoint/NR/rdonlyres/12804AEB-BC194A70-834C-69EBC8AE7ABE/0/EDMP_May03pdf

[21] WHO (2013) Antimicrobial resistance: Fact sheet. World Health Organization (WHO), Geneva. http://www.who.int/mediacentre/factsheets/fs194/en/

[22] Awad, A.I. and Eltayeb, I.B. (2007) Self-medication practices with antibiotics and antimalarials among Sudanese undergraduate university students. The Annals of Pharmacotherapy, 41, 1249-1255. http://dx.doi.org/10.1345/aph.1K068

[23] Okeke, I.N., Lamikanra, A. and Edelman, R. (1999) Socioeconomic and behavioral factors leading to acquired bacterial resistance to antibiotics in developing countries. Perspectives. Emerging Infectious Diseases, 5, 18-27. http://dx.doi.org/10.3201/eid0501.990103

[24] WHO (2006) Partnerships for malaria control: engaging the formal and informal private sectors in child survival. WHO Ref. No: TDR/GEN/06.1, World Health Organization, Geneva.

http://www.who.int/tdr/publications/documents/partner malaria.pdf

[25] Curry, M., Sung ,L., Arroll, B., Goodyear-Smith, F., Kerse, N. and Norris P. (2006) Public views and use of antibiotics for the common cold before and after an education campaign in New Zealand. Journal of the New Zealand Medical Association, 119, U1957.

[26] Nambiar, L. (2003) The search for essential drugs. MURJ: Features, 8, 21-22.

[27] Brahma, D., Marak, M. and Wahlang, J. (2012) Rational use of drugs and irrational drug combinations. The Internet Journal of Pharmacology, 10, 1-5. http://dx.doi.org/10.5580/2b59 
[28] Chan, G.C. and Tang, S.F. (2006) Parental knowledge, attitudes and antibiotic use for acute upper respiratory tract infection in children attending a primary healthcare clinic in Malaysia. Singapore Medical Journal, 47, 266270.

[29] Abba, K., Sinfield, R., Hart, C.A. and Garner, P. (2009) Antimicrobial drugs for persistent diarrhoea of unknown or non-specific cause in children under six in low and middle income countries: Systematic review of randomized controlled trials. BMC Infectious Diseases, 9, 24. http://dx.doi.org/10.1186/1471-2334-9-24

[30] Cizman, M. (2003) The use and resistance to antibiotics in the community. International Journal of Antimicrobial Agents, 21, 297-307. http://dx.doi.org/10.1016/S0924-8579(02)00394-1

[31] Nyazema, N., Viberg, N., Khoza, S., Vyas, S., Kumaranayake, L., Tomson, G. and Lundborg, C.S. (2007) Low sale of antibiotics without prescription: A cross-sectional study in Zimbabwean private pharmacies. Journal of Antimicrobial Chemotherapy, 59, 718-726.

[32] Ombaka, E., Etemesi, S. and Nyagah, J. (2006) Promoting rational use of medicines. CONTACT: Ecumenical Pharmaceutical Network (EPN), 183, 1-32. http://www.epnetwork.org

[33] Bantar, C., Vesco, E., Heft, C., Salamone, F., Krayeski, M., Gomez, H., Coassolo, M.A., Fiorillo, A., Franco, D., Arango, C., Duret, F. and Oliva, M.E. (2004) Replacement of broad-spectrum cephalosporins by piperacillintazobactam: Impact on sustained high rates of bacterial resistance. Antimicrobial Agents and Chemotherapy, 48, 392-395. http://dx.doi.org/10.1128/AAC.48.2.392-395.2004

[34] Hennessy, T.W., Petersen, K.M., Bruden, D., Parkinson, A.J., Hurlburt, D., Getty, M., Schwartz, B. and Butler, J.C. (2002) Changes in antibiotic prescribing practices and carriage of penicillin-resistant Streptococcus pneumoniae: A controlled intervention trial in rural Alaska. Clinical Infectious Diseases, 34, 1543-1550. http://dx.doi.org/10.1086/340534

[35] Agarwal, R.A.K., Acharya, U., Christina, P., Sreenivas, V. and Seetaraman, S. (2007) Impact of simple interventions on neonatal mortality in a low-resource teaching hospital in India. Journal of Perinatology, 27, 44-49. http://dx.doi.org/10.1038/sj.jp.7211620

[36] Mainous, A.G., Hueston, W.J., Love, M.M., Evans, M.E. and Finger, R. (2000) An evaluation of statewide strategies to reduce antibiotic overuse. Family Medicine, 32, 22-29.

[37] Apisarnthanarak, A., Danchaivijitr, S., Khawcharoenporn, T., Limsrivilai, J., Warachan, B., Bailey, T.C., Fraser, V.J. and the Thammasart University Antibiotic Management Team (2006) Effectiveness of education and an antibioticcontrol program in a tertiary care hospital in Thailand. Clinical Infectious Diseases, 42, 768-775.

[38] Bantar, C., Sartori, B., Vesco, E., Heft, C., Saúl, M., Salamone, F. and Oliva, M.E. (2003) A hospital wide intervention program to optimize the quality of antibiotic use: Impact on prescribing practice, antibiotic consumption, cost savings, and bacterial resistance. Clinical Infectious
Diseases, 37, 180-186. http://dx.doi.org/10.1086/375818

[39] Freemantle, N., Harvey, E.L., Wolf, F., Grimshaw, J.M., Grilli, R. and Bero, L. (2004) Printed educational materials: Effects on professional practice and health care outcomes. Cochrane Database of Systematic Reviews, 2, CD000172.

http://dx.doi.org/10.1002/14651858.CD000172

[40] Chalker, J., Ratanawijitrasin, S., Chuc, N., Petzold, M. and Tomson, G. (2005) Effectiveness of a multi-component intervention on dispensing practices at private pharmacies in Vietnam and Thailand: A randomized controlled trial. Social Science \& Medicine, 60, 131-141. http://dx.doi.org/10.1016/j.socscimed.2004.04.019

[41] Reyes-Morales, H., Flores-Hernández, S., Tomé-Sandoval, P. and Pérez-Cuevas, R. (2009) A multifaceted education intervention for improving family physicians' case management. Family Medicine, 41, 277-284.

[42] INRUD (2009) Progress in the rational use of medicines. International Network for the Rational Use of Drugs (INRUD) Newsletter. INRUD News, 19, 1-15. http://www.inrud.org/documents/upload/INRUD_News_ Vol19_No1_Jul2009_Final.pdf

[43] LeGrand, A., Hogerzeil, H.V. and Haaijer-Ruskamp, F.M. (1999) Intervention research in rational use of drugs: A review. Oxford University Press, Health Policy and Planning, 14, 89-102.

http://dx.doi.org/10.1093/heapol/14.2.89

[44] Cochrane (2007) How to develop a search strategy for a Cochrane Review. Cochrane Haematological Malignancies Group, Naumann, 1-10.

http://chmg.cochrane.org/sites/chmg.cochrane.org/files/u ploads/How\%20to\%20develop\%20a\%20search\%20strate gy-support-manual.pdf

[45] Jamtvedt, G., Young, J.M., Kristoffersen, D.T., O’Brien, M.A.T. and Oxman, A.D. (2004) Audit and feedback: Effects on professional practice and health care outcomes. Cochrane Database of Systematic Reviews, 2, CD000259. http://dx.doi.org/10.1002/14651858.CD000259.pub2

[46] Higgins, J.P.T. and Green, S. (2006) Cochrane handbook for systematic reviews of interventions 4.2.6. In: The Cochrane Library, Issue 4, John Wiley \& Sons, Ltd. Chichester, 1-181.

[47] Armstrong, R., Jackson, N., Doyle, J. and Waters, E. (2005) It's in your hands: The value of handsearching in conducting systematic reviews of public health interventions. Journal of Public Health, 27, 388-391. http://dx.doi.org/10.1093/pubmed/fdi056

[48] Sampson, M., Zhang, L., Morrison, A., Barrowman, N.J., Clifford, T.J., Platt, R.W., et al. (2006) An alternative to the hand searching gold standard: Validating methodological search filters using relative recall. BMC Medical Research Methodology, 6, 33. http://dx.doi.org/10.1186/1471-2288-6-33

[49] Schöpfe, J. (2011) Towards a Prague Definition of Grey Literature. Dans Proceedings-Twelfth International Conference on Grey Literature: Transparency in Grey Literature. Grey Tech Approaches to High Tech Issues, Prague, 6-7 December 2010, sic_00581570, Version 131 Mar 2011. 
http://archivesic.ccsd.cnrs.fr/docs/00/58/15/70/PDF/GL_1 2_Schopfel_v5.2.pdf

[50] Higgins, J.P.T. and Green, S. (2008) Cochrane handbook for systematic reviews of interventions. Version 5.0.0. http://www.cochrane.org/resources/handbook/Handbook4 .2.6Sep2006.pdf; http://www.mrc-bsu.cam.ac.uk/cochrane/handbook500/

[51] Pollock, L. and Westmorland, L.B. (1998) Critical review form-Qualitative and quantitative studies. McMaster University Occupational Therapy Evidence-Based Practice Research Group, Hamilton.

[52] Zvi, M. and Chung, K.C. (2007) Systematic reviews: A primer for plastic surgery research. Plastic and Reconstructive Surgery Journal, 120, 1834-1841.

[53] Olson, C.M., Rennie, D., Cook, D., Dickersin, K., Flanagin, A., Hogan, J.W., Zhu, Q., Reiling, J. and Pace, B. (2002) Publication bias in editorial decision making. Journal of American Medical Association (JAMA), 287, 2825-2828.

http://dx.doi.org/10.1001/jama.287.21.2825

[54] Lexchin, J., Bero, L.A., Djulbegovic, B. and Clark, O. (2003) Pharmaceutical industry sponsorship and research outcome and quality: Systematic review. British Medical Journal, 326, 1167-1170. http://dx.doi.org/10.1136/bmj.326.7400.1167

[55] Stern, J.M. and Simes, R.J. (1997) Publication bias: Evidence of delayed publication in a cohort study of clinical research projects. British Medical Journal, 315, 640-645. http://dx.doi.org/10.1136/bmj.315.7109.640

[56] Greenhalgh, T. (2006) How to read a paper: The basics of evidence-based medicine. 3rd Edition, Wiley-Blackwell publishers-BMJ Books, Hoboken, 64, 120.

[57] Armstrong, R. and Waters, E. (2007) Systematic review of health promotion and public health intervention: Guideline for systematic reviews in health promotion and public health task force. The Cochrane Collaboration, Ver.2: 1-52.

http://ph.cochrane.org/sites/ph.cochrane.org/files/uploads/ Guidelines\%20HP_PH\%20reviews.pdf

[58] Babor, T.F. and McGovern, T. (2008) Dante's inferno: Seven deadly sins in scientific publishing and how to avoid them. Publishing Addiction Science: A Guide for the Perplexed, Chapter 7, 87-104. http://www.who.int/substance_abuse/publications/publish ing_addiction_science_chapter7.pdf

[59] NLM (2010) Medical Subject Heading (MeSH): Natinal Library of Medicine (NLM).

http://www.nlm.nih.gov/mesh/MBrowser.html

[60] Chalmers, I., Hedges, L.V. and Cooper, H. (2002) A brief history of research synthesis. Evaluation \& the Health Professions, 25, 12-37.

http://dx.doi.org/10.1177/0163278702025001003

[61] Belsey, J. (2009) What is evidence-based medicine? Sanofi-aventis, 2nd Edition, NPR09/1110, 1-10. http://www.medicine.ox.ac.uk/bandolier/painres/downloa d/whatis/ebm.pdf

[62] Moher, D. and Tricco, A.C. (2008) Issues related to the conduct of systematic reviews: A focus on the nutrition field. American Journal of Clinical Nutrition, 88, 11911199. http://www.ajcnorg/cgi/reprint/88/5/1191pdf

[63] Stone, P.W. (2002) Popping the (PICO) question in research and evidence-based practice. Applied Nursing Research, 15, 197-198. http://dx.doi.org/10.1053/apnr.2002.34181

[64] Pirozzo, S. and Irish, E. (2010) Searching the medical literature. Dan Mayer: Essential evidence-based medicine. 2nd Edition, Cambridge University Press, Edinburgh Building, Cambridge, Chapter 5, 33-55.

http://www.nogracias.eu/wp-content/uploads/2011/06/Ess ential_Evidence_based_Medicine.pdf

[65] AVERT (2010) Age of consent. avert HIV and AIDS worldwide, through education, treatment and care. AVERT.org. http://www.avertorg/age-of-consenthtm

[66] ICAP (2002) Drinking age limits. International Center for Alcohol Policies (ICAP), ICAP Reports 4, 1-10. http://www.icap.org/portals/0/download/all_pdfs/icap_rep orts_english/report4.pdf

[67] Thomas, C. (2009) Forced and early marriage: A focus on Central and Eastern Europe and former Soviet Union countries with selected laws from other countries. Expert Group Meeting on good practices in legislation to address harmful practices against women, United Nations Conference Centre, Addis Ababa, Ethiopia; United Nations Division for the Advancement of Women, EGM/GPLHP/ 2009/EP.08, Minnesota, 1-19.

http://www.un.org/womenwatch/daw/egm/vaw_legislatio n_2009/Expert\%20Paper\%20EGMGPLHP\%20_Cheryl\% 20Thomas\%20revised_pdf

[68] OECD (2013) Economic, environmental and social statistics. Organization for Economic Co-operation and Development (OECD), OECD Factbook 2013.

http://www.mzv.sk/App/wcm/media.nsf/vw_ByID/ID_C BD2FABFAB495B52C1257648003959F2_SK/\$File/Gro wing\%20Unequal.pdf

[69] WorldBank (2010) Country classification: Data and statistics.

http://web.worldbank.org/WBSITE/EXTERNAL/DATAS TATISTICS/0,,contentMDK:20420458 menuPK:641331 56 pagePK:64133150 piPK:64133175 theSitePK:23941 9,00.html; http://go.worldbank.org/K2CKM78CC0

[70] Gough, D. (2007) Weight of evidence: A framework for the appraisal of the quality and relevance of evidence. Research Papers in Education, 22, 213-228.

[71] Spencer, L., Ritchie, J., Lewis, J. and Dillon, L. (2003) Quality in qualitative evaluation: A framework for assessing research evidence. A Quality Framework, National Centre for Social Research, 1-20.

http://www.civilservice.gov.uk/wp-content/uploads/2011/ 09/a_quality_framework_tcm6-38740.pdf

[72] Gough, D. (2007) Dimensions of difference in evidence reviews (Overview; I. Questions, evidence and methods; II. Breadth and depth; III. Methodological approaches; IV. Quality and relevance appraisal; V. Communication, interpretation and application). Series of Six Posters Presented at National Centre for Research Methods Meeting, Manchester, January 2007, EPPI-Centre, London.

[73] Vlayen, J., Aertgeerts, B., Hannes, K., Sermeus, W., Ra- 
maekers, D. (2005) A systematic review of appraisal tools for clinical practice guidelines: Multiple similarities and one common deficit. International Journal for Quality in Health Care, 17, 235-242.

http://dx.doi.org/10.1093/intqhc/mzi027

[74] Armbruster, D. (2007) Categories of quality: WHO recommendations for the prevention of postpartum hemorrhage. Results from a WHO Technical Consultation-18-20 October 2006. World Health Organization, Geneva.

[75] WHO (2013) Tuberculosis (TB): Global tuberculosis report 2013. World Health Organization (WHO) publications on tuberculosis.

www.who.int/iris/bitstream/10665/91355/1/97892415646 56_eng.pdf

[76] Falzon, D., Gandhi, N., Migliori, G.B., Sotgiu, G., Cox, H.S., Holtz, T.H., et al. (2013) Resistance to fluoroquinolones and second-line injectable drugs: Impact on multidrug-resistant TB outcomes. The European Respiratory Journal, 42, 156-168. http://dx.doi.org/10.1183/09031936.00134712

[77] CAHE (2004) Efficacy of manipulation and moblisation for headaches: Systematic review protocol. The Joanna Briggs Institute, Centre conducting review. Centre for Allied Health Evidence, University of South Australia, Adelaide, 1-14.

[78] Zaza, S., Wright-De Aguero, L.K., Briss, P.A., Truman, B.I., Hopkins, D.P., Hennessy, M.H., et al. (2000) Data collection instrument and procedure for systematic reviews in the guide to community preventive services. American Journal of Preventive Medicine, 18, 44-74. http://dx.doi.org/10.1016/S0749-3797(99)00122-1

[79] Bloomfield, S.F., Exner, M., Fara, G.M., Nath, K.J., Scott, E.A. and Voorden, C.V.D. (2009) The global burden of hygiene-related diseases in relation to the home and community: A report celebrating 10 years of the International Scientific Forum on home Hygiene. International Scientific Forum on home Hygiene (IFH), London, 1-88.

[80] Bachou, H., Tylleskär, T., Kaddu-Mulindwa, D.H. and Tumwine, J.K. (2006) Bacteraemia among severely malnourished children infected and uninfected with the human immunodeficiency virus-1 in Kampala, Uganda. BMC Infectious Diseases, 6, 160.

[81] Ojulong, J., Mwambu, T., Jolobo, M., Agwu, E., Bwanga, F., Najjuka, C. and Kaddu-Mulindwa, D. (2008) Prevalence of Methicillin resistant Staphylococcus aureus (MRSA) among isolates from surgical site infections in Mulago hospital- Kampala, Uganda. The Internet Journal of Infectious Diseases, 7, 1-5. http://ispub.com/IJID/7/2/10326
[82] Gyssens, I.C. (2001) Quality measures of antimicrobial drug use. International Journal of Antimicrobial Agents, 17, 9-19. http://dx.doi.org/10.1016/S0924-8579(00)00208-9

[83] Geissler, P.W., Meinert, L., Prince, R., Nokes, C., AagaardHansen, J., Jitta, J. and Ouma, J.H. (2001) Self-treatment by the Kenyan and Ugandan school children and the need for school-based education. Oxford University Press, Health Policy and Planning, 16, 362-371. http://dx.doi.org/10.1093/heapol/16.4.362

[84] UMoH (2009) Uganda national communication strategy for promoting rational use of medicines. Uganda Ministry of Health, Kampala.

[85] Saniel, M.C., Acuin, C., Arciaga, R.S., Lansang, M.D., Naidas, O.D., Sevilleja, E.A., et al. (2004) Effect of two dissemination strategies in improving private practitioners' adherence to evidence-based practice guidelines for urinary tract infection in a developing country: A quasi-experimental study: Abstract. ICIUM 2004: Second International Conference on Improving Use of Medicines (ICIUM), Chiang Mai, 30 March-2 April 2004, Abstracts.

[86] Akter, S.F., Heller, R.D., Smith, A.J. and Milly, A.F. (2009) Impact of a training intervention on use of antimicrobials in teaching hospitals. The Journal of Infection in Developing Countries, 3, 447-451. http://dx.doi.org/10.3855/jidc.416

[87] Bhavnani, D., Phatinawin, L., Chantra, S., Olsen, S.J., Simmerman, J.M. (2007) The influence of rapid influenza diagnostic testing on antibiotic prescribing patterns in rural Thailand. International Journal of Infectious Diseases, 11, 355-359. http://dx.doi.org/10.1016/j.ijid.2006.09.009

[88] Apisarnthanarak, A., Pinitchai, U., Thongphubeth, K., Yuekyen, C., Warren, D.K. and Fraser, V.J. (2008) A multifaceted intervention to reduce pandrug-resistant Acinetobacter baumannii colonization and infection in 3 intensive Care Units in a Thai Tertiary Care Center: A 3-year study. Clinical Infectious Diseases, 47, 760-767. http://dx.doi.org/10.1086/591134

[89] Yudatiningsih, I. and Sunartono, H. (2004) Long-term impact of an MTP approach to reduce inappropriate use of antibiotics in acute respiratory infections: Abstract. ICIUM 2004: Second International Conference on Improving Use of Medicines (ICIUM), Chiang Mai, Thailand, 30 March-2 April 2004, Abstracts.

[90] Liu, S.A., Chiu, Y.T., Lin, W.D. and Chen, S.J. (2008) Using information technology to reduce the inappropriate use of surgical prophylactic antibiotic. European Archives of Oto-Rhino-Laryngology, 265, 1109-1112. http://dx.doi.org/10.1007/s00405-008-0588-x 